\title{
PENGARUH REPUTASI UNDERWRITER, UKURAN PERUSAHAAN, DAN RETURN ON EQUITY TERHADAP UNDERPRICING SAAT IPO DI BEI
}

\author{
Anak Agung Gede Jayanarendra ${ }^{1}$ \\ Ni Luh Putu Wiagustini ${ }^{2}$ \\ ${ }^{1,2}$ Fakultas Ekonomi dan Bisnis Universitas Udayana, Bali, Indonesia \\ e-mail: jayanarendra88@gmail.com
}

\begin{abstract}
ABSTRAK
Penelitian ini bertujuan untuk menganalisis pengaruh faktor-faktor yang mempengaruhi underpricing pada saat Initial Public Offering (IPO). Sampel penelitian ini berjumlah sebanyak 102 perusahaan yang mengalami underpricing pada tahun 2013-2017 yang tercatat di Bursa Efek Indonesia, pengembilan sampel dilakukan berdasarkan teknik purposive sampling, dengan kriteria perusahaan yang melakukan IPO di BEI pada periode 2013-2017 serta mengalami fenomena underpricing. Metode analisis data menggunakan regresi linear berganda dengan program SPSS 20. Temuan penelitian adalah ukuran perusahaan dan return on equity berpengaruh negatif signifikan terhadap underpricing, sedangkan reputasi underwriter tidak berpengaruh terhadap underpricing. Hal ini menunjukkan bahwa semakin tinggi ukuran perusahaan dan return on equity, maka underpricing pada perusahaan semakin rendah. Berbeda dengan reputasi underwriter yang tidak memiliki pengaruh terhadap underpricing.

Kata kunci: initial public offering, underpricing, reputasi underwriter, ukuran perusahaan, return on equity
\end{abstract}

\section{ABSTRACT}

This study aims to analyze the influence of the factors that influence underpricing on the Initial Public Offering (IPO). The sample of this study amounted to 102 companies that experienced underpricing in 2013-2017 which were listed on the Indonesia Stock Exchange, the sample was conducted based on purposive sampling technique, with the criteria of companies conducting IPOs on the IDX in the period 2013-2017 and experiencing the phenomenon of underpricing. The method of data analysis uses multiple linear regression using the SPSS 20 program. The findings of the study are that company size and return on equity have a significant negative effect on underpricing, while the underwriter's reputation does not affect underpricing. This shows that the higher the size of the company and return on equity, the lower the underpricing of the company. Unlike the reputation of the underwriter who has no influence on underpricing.

Keywords: initial public offering, underpricing, underwriter reputation, firm size, return on equity 


\section{PENDAHULUAN}

Undang-Undang Pasar Modal Republik Indonesia Nomor 8 Tahun 1995 pasal 1 butir 13 menyatakan bahwa pasar modal adalah kegiatan yang bersangkutan dengan penawaran umum dan perdagangan efek perusahaan publik yang berkaitan dengan efek yang diterbitkannya, serta lembaga dan potensi yang berkaitan dengan efek. Pasar modal mempertemukan pihak yang memiliki kelebihan dana dengan yang membutuhkan dana dan memfasilitasi jual beli sekuritas yang umumnya berumur lebih dari satu tahun, seperti saham dan obligasi (Tandelilin, 2010:26).

Seiring perkembangan perekonomian di Indonesia, suatu perusahaan memerlukan dana yang tidak sedikit untuk keperluan operasional dan pengembangan perusahaan. Perusahaan mempunyai berbagai macam alternatif sumber pendanaan, ada berasal dari dalam dan juga dari luar perusahaan. Selain bersumber dari laba dari aktivitas operasional, perusahaan juga mempunyai strategi lainnya untuk memperoleh sumber pendanaan dengan melakukan proses go public berupa memperdagangkan saham dengan cara mendaftarkan diri di Bursa Efek Indonesia. (Darmadji dan Fakhruddin, 2012:44). Hermuningsih (2012:60) menyatakan bahwa, go public adalah sebuah proses untuk menawarkan saham atau obligasi perusahaan kepada masyarakat untuk pertama kalinya di pasar perdana yang menerbitkan efek dan melakukan penjualan efek. Menurut Tandeliln (2010:28), perusahaan emiten untuk pertama kali melakukan transaksi juak beli sekuritasnya kepada investor terjadi di pasar perdana, sedangkan tempat perdagangan atau jual beli sekuritas oleh dan antar investor setelah sekuritas dijual di pasar perdana dinamakan pasar sekunder. Proses perusahaan untuk pertama kalinya memperdagangkan sekuritas disebut dengan Initial Public Offering (IPO) 
atau penawaran umum perdana. Berikut adalah data perusahaan yang melakukan Initial Public Offering (IPO) pada tahun 2013-2017.

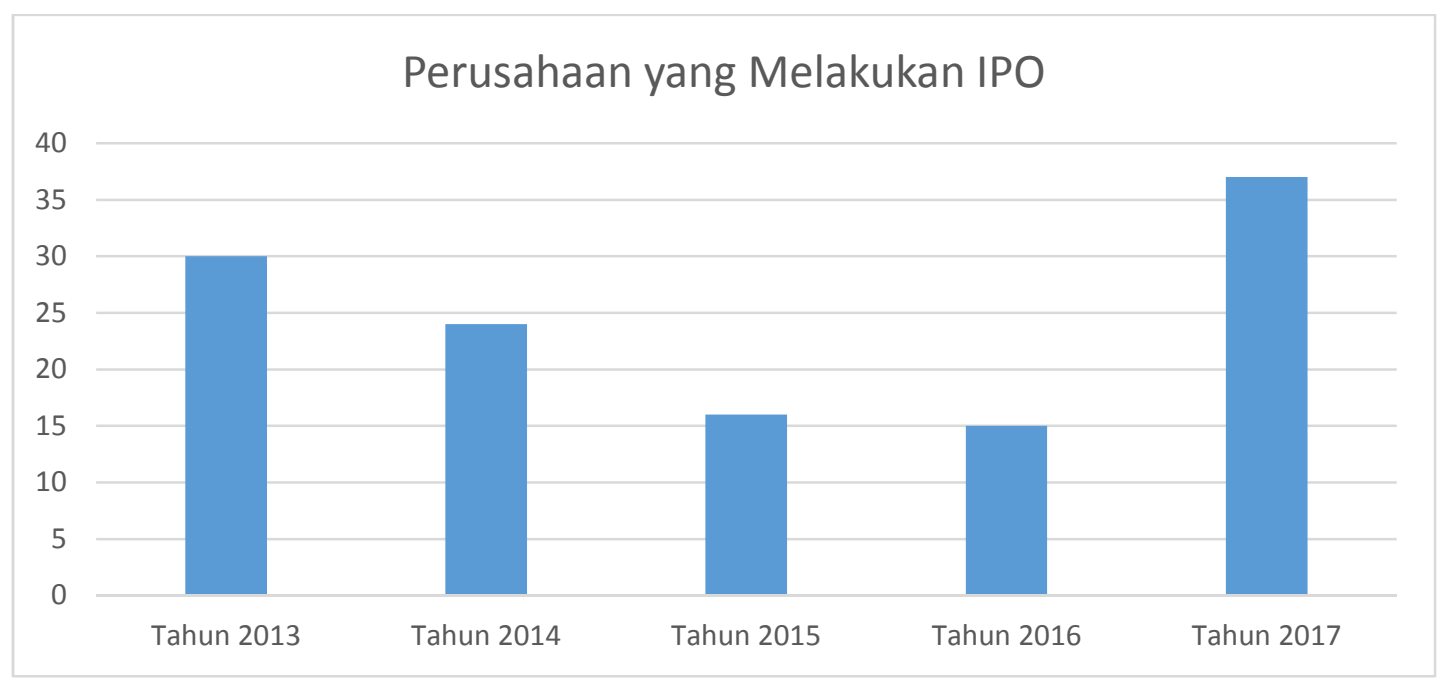

Gambar 1. Perusahaan yang Melakukan Initial Public Offering Tahun 20132017

Sumber: Data diolah, 2018

Jumlah perusahaan yang melakukan IPO mengalami tren yang menurun dari tahun 2013 sampai dengan 2016, kemudian meningkat signifikan pada tahun 2017, sesuai dengan grafik di atas. Kegiatan IPO untuk suatu perusahaan menjadi fenomena umum yang sering terjadi di pasar modal dengan adanya perbedaan jumlah atau selisish antara harga saham di pasar sekunder dengan harga saham di pasar perdana atau saat Initial Public Offering yang dikenal dengan istilah underpricing (Puspita, 2011). Sunariyah (2011:119) mengatakan bahwa, underpricing adalah fenomena yang terjadi ketika harga saham perdana yang harganya di bawah harga pasar. Membeli saham di penawaran perdana mendapatkan initial return yang tinggi bagi investor (Jogiyanto, 2013:36), sedangkan bagi emiten, underpricing yang tinggi adalah merugikan karena tambahan dana hasil IPO yang diperoleh menjadi tidak maksimal. Fenomena 
underpricing terjadi karena adanya asimetri informasi (Retnowati, 2013). Berdasarkan data yang diperoleh dari situs $w w w . i d x . c o . i d$, fenomena underpricing yang terjadi di Indonesia, dalam kurun 5 tahun terakhir yaitu tahun 2013 sampai dengan 2017, terdapat 122 perusahaan yang melakukan penawaran umum pertama kali ke publik atau Initial Public Offering (IPO), 102 diantaranya mengalami kondisi underpricing dengan berbagai macam faktor yang mempengaruhi. Underpricing terjadi ketika harga saham perusahaan dinilai lebih rendah dari kondisi yang sesungguhnya oleh underwriter.

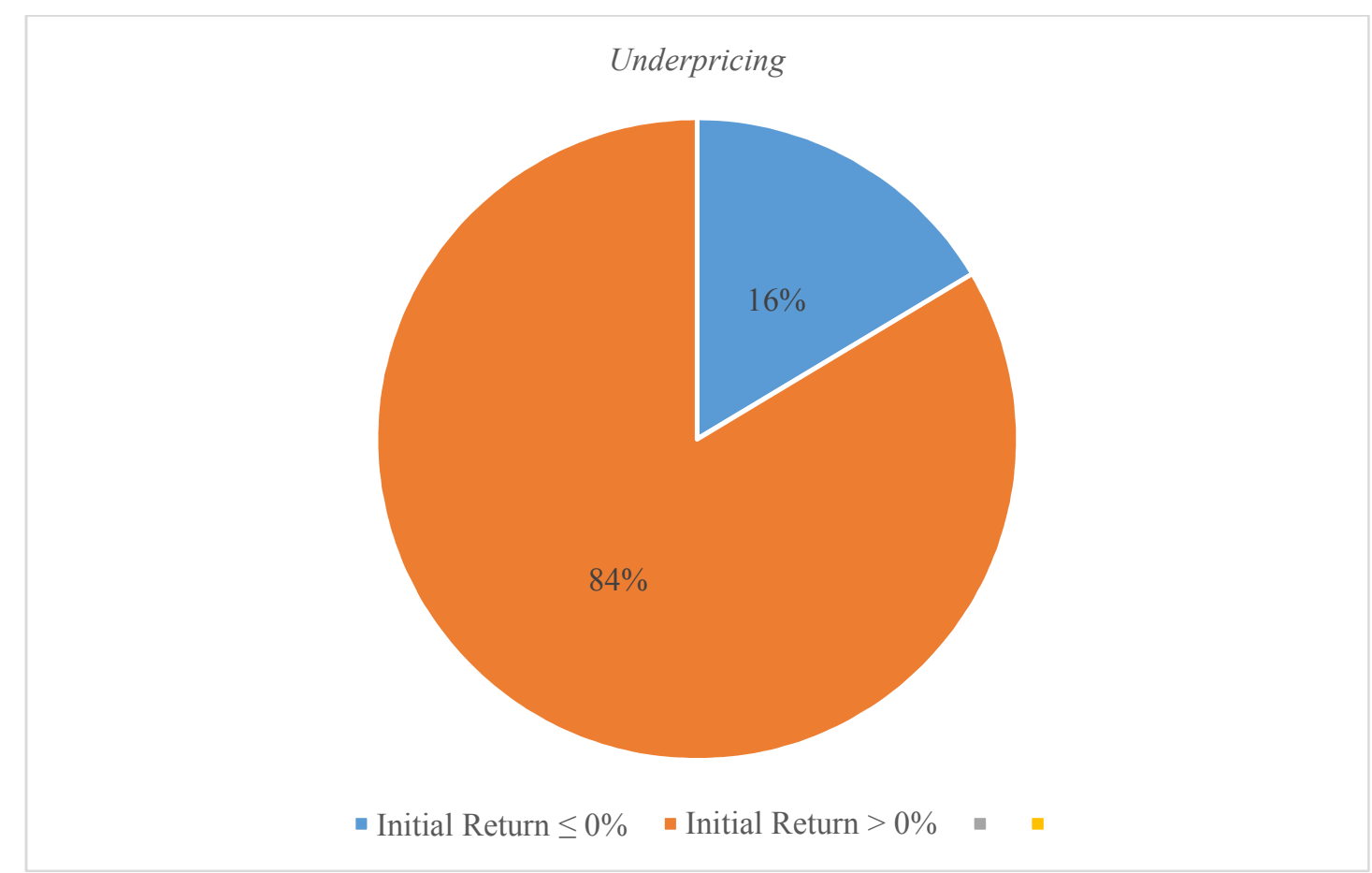

Gambar 2. Persentase Perusahaan yang Mengalami Underpricing Tahun 2013 $-2017$

Sumber: Data diolah, 2018

Underwriter adalah pihak yang menjamin emisi untuk suatu perusahaan.yang akan memperdagangkan sahamnya pada pasar modal (Fahmi, 2012:57). Underwriter dalam hal ini memperoleh informasi lebih baik terkait permintaan 
saham-saham emiten, dibandingkan emiten itu sendiri. Underwriter yang mempunyai reputasi tinggi atau citra yang baik, tidak akan melakukan aksi penjaminan terhadap perusahaan yang mempunyai citra rendah, sehingga hal ini akan mendapatkan kepercayaan dari investor yang akan menanamkan modalnya (Pratama, 2017).

Underpricing bisa juga terjadi karena ukuran dari sebuah perusahaan yang tercermin dari total aset yang terdapat pada neraca dalam laporan keuangan. Aset perusahaan yang semakin besar mencerminkan ukuran perusahaan yang semakin besar pula. Arman (2012) mengindikasikan bahwa semakin besar atau tinggi ukuran dari suatu perusahaan, maka akan lebih cenderung dikenal masyarakat, sehingga masyarakat yang menjadi calon investor akan optimis akan prospek kedepan dari perusahaan tersebut dan underpricing akan dapat diminimalisasi.

Sebuah perusahaan terbentuk dari modal saham yang dimiliki pemilik perusahaan, sehingga tingkat bagi hasil dari pemodal saham atas investasi yang dilakukan bisa dihitung dengan menggunakan rasio return on equity (ROE). Semakin tinggi perolehan laba perusahaan, maka berbanding lurus akan permintaan saham dari perusahaan tersebut. Permintaan yang tinggi akan berakibat pada kenaikan penawaran harga saham di pasar sekunder, maka profitabilitas yang tinggi dari suatu perusahaan yang go public akan mengurangi ketidakpstian bagi investor sehingga bisa menurunkan tingkat underpricing.

Penelitian tentang reputasi underwriter, ukuran perusahaan serta return on equity yang mempengaruhi tingkat underpricing sudah banyak dilakukan seperti penelitian dari Pratama (2017), Asrini (2017) dan Sari (2017) menemukan bahwa 
Anak Agung Gede Jayanarendra, Pengaruh Reputasi Underwriter...

reputasi underwriter berpengaruh negatif terhadap underpricing. Kartika (2017) dan Irawan (2016) menemukan bahwa reputasi underwriter tidak berpengaruh terhadap underpricing. Sebuah penelitian dari Demovski (2011) dan Jones (2010) menunjukan suatu hasil yang berbeda, bahwa reputasi underwriter berpengaruh positif signifikan terhadap underpricing.

Asrini (2017), Sari (2017) dan Maolaa (2016) dalam penelitiannya menemukan hasil bahwaa ukuran perusahaann tidak berpengaruh terhadap underpricing. Hasil penelitian Kartika (2017), Pratama (2017) dan Pearlstein (2013) menemukan jika ukuran perusahaan berpengaruh negatif terhadap underpricing. Berbeda dengan hasil penelitian yang dilakukan oleh Islam et al. (2010) yang menemukan bahwa ukuran perusahaan berpengaruh positif terhadap underpricing.

Penelitian yang dilakukan Dewi dkk. (2017) dan Witjaksono (2012) menemukan hasil bahwa underpricing dipengaruhi negatif oleh variabel return on equity. Irawan (2016), Apriliani (2015) dan Rosyidah (2014) mendapat temuan jika return on equity tidak berpengaruh terhadap underpricing.

Rumusan masalah dalam penelitian ini, yakni apakah reputasi underwriter, ukuran perusahaan dan return on equity memiliki pengaruh signifikan terhadap underpricing saat Initial Public Offering (IPO), dengan menganalisis pengaruh signifikansi faktor-faktor yang mempengaruhi underpricing pada saat Initial Public Offering (IPO) sebagai tujuan dari penelitian ini.

Penelitian ini diharapkan secara teoretis bisa berguna dalam penambahan ilmu pengetahuan terkait dengan faktor-faktor yang mempengaruhi underpricing 
saat IPO dan juga informasi untuk akademisi serta dapat menjadi referensi bagi peneliti lain ataupun peneliti selanjutnya yang berhubungan dengan fenomena underpricing. Secara praktis, penelitian ini diharapkan bisa bermanfaat bagi investor dan perusahaan untuk dapat mengetahui bagaimana fenomena underpricing ini terjadi, serta faktor apa saja yang mempengaruhinya agar kedepannya, baik invetor maupun perusahaan tidak salah mengambil keputusan untuk mengambil keputusan.

Asimetri informasi terjadi ketika underwriter mempunyai informasi lebih dibanding perusahaan dan juga investor karena telah memahami pergerakan pasar serta memiliki pengalaman di pasar modal, sehingga sebuah perusahaan yang akan menuju proses Initial Public Offering (IPO) memercayai underwriter terkait harga sahamnya. Teori sinyal lebih menekankan pada pentingnya informasi yang akan dikeluarkan oleh perusahaan terhadap keputusan investasi pihak luar perusahaan yang dalam hal ini adalah investor. Tindakan ini menunjukkan bahwa pihak manajemen perusahaan selalu melaksanakan pengungkapan informasi yang diperlukan dan diinginkan oleh investor, khususnya jika informasi yang dikeluarkan manajemen perusahaan tersebut adalah sebuah berita yang baik bagi keperluan mereka. Informasi perusahaan adalah sebuah sinyal bagi investor dalam menentukan keputusan berinvestasi yang akan dilakukan. Signalling theory menyebutkan bahwa pengungkapan informasi yang berkaitan dengan perusahaan merupakan sinyal bagi investor, dalam menentukan atau memilih keputusan untuk investasi. 
Pasar modal merupakan sarana perusahaan untuk meningkatkan kebutuhan dana jangka panjang dengan menjual saham atau mengeluarkan obligasi. Menurut Sunariyah (2011:12), pasar modal terdiri atas pasar perdana (primary market) adalah pasar tempat dimana surat berharga yang baru dikeluarkan pertama kali dijual, berupa penawaran perdana ke publik dan yang kedua yaitu pasar sekunder (secondary market) yaitu tempat perdagangan surat beharga yang sudah beredar (Jogiyanto, 2014:33).

Menurut Darmadji dan Fakhruddin (2012:58), go public adalah kegiatan yang dilakukan oleh emiten dalam bentuk penawaran saham atau efek lainnya. Kegiatan yang pertama kali dilakukan perusahaan yakni akan menjual saham atau obligasi kepada masyarakat umum disebut dengan Initial Public Offering (IPO) (Samsul, 2006:70). Tujuan sebuah perusahaan mengambil keputusan untuk menawarkan saham di pasar modal adalah untuk menambah sumber pendanaan yang bisa didapatkan, baik yang nantinya digunakan untuk membantu melunasi utang yang dialami maupun melancarkan ekspansi perusahaan (Pratama, 2017).

Pihak yang melakukan kontrak perjanjian dengan emiten untuk melakukan sebuah penawaran umum bagi kepentingan emiten tersebut dinamakan underwriter (Samsul, 2006:75). Fungsi underwriter adalah untuk menjamin sebuah emiten dan melakukan pembayaran terhadap nilai total seluruh efek yang dijual kepada emiten serta sebagai perwakilan para penjamin emisi pada saat berhubungan dengan emiten dan dengan pihak ketiga (Hermuningsih, 2012:50). Menurut Sunariyah (2011:115), kemampuan dan pengalaman underwriter sangat menentukan sukses atau tidaknya suatu go public di perusahaan. 
Ukuran perusahaan yang dicerminkan oleh total keseluruhan aset perusahaan yang terdapat pada neraca dalam laporan keuangan merupakan salah satu faktor terjadinya tingkat underpricing karena total aset menunjukkan kekayaan perusahaan. Investor merasa percaya terhadap prospek masa depan dari sebuah perusahaan berskala besar karena total aset yang besar dari perusahaan berskala atau dengan ukuran besar menunjukkan kekayaan sebanding pula dan meminimalisasi ketidakkepastian prospek jangka panjang perusahaan sehingga dapat diketahui dengan mudah.

Berdasarkan perhitungan akuntansi, return on equity (ROE) secara umum dapat dihitung dengan ukuran kinerja dan dihitung sebagai laba bersih perusahaan dibagi total ekuitas pemegang saham biasa (Tandelilin 2010:315), berdasarkan perhitungan akuntansi. Brigham dan Houston (2010:149), menyebutkan bahwa perhitungan rasio bersih terhadap ekuitas biasa yang mengukur tingkat pengembalian modal atas investasi pemegang saham biasa merupakan perhitungan return on equity. Harapan investor yang semakin besar terhadap tingkat pengembalian, menjadikan semakin besar pula nilai ROE, yang dianggap menguntungkan bagi perusahaan karena semakin tinggi ROE, maka kemampuan perusahaan untuk menghasilkan laba pada masa yang akan datang juga lebih tinggi.

Kerangka konseptual dalam penelitian ini menunjukkan pengaruh antar variabel dependen dan independennya. Kerangka konseptual dalam penelitian ini dituangkan dalam gambar 2 sebagai berikut. 


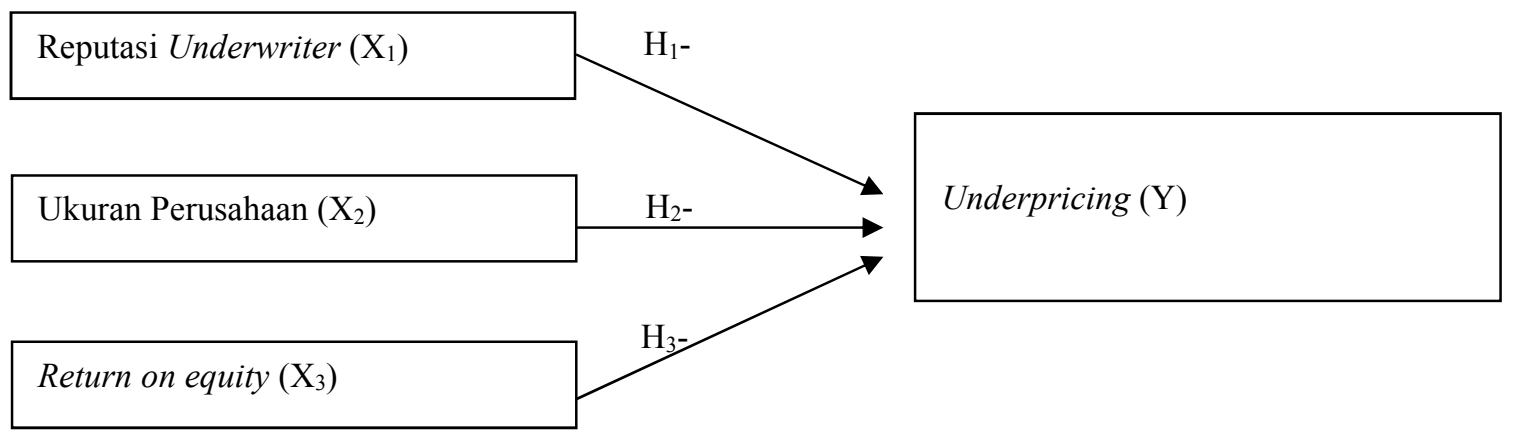

Gambar 2. Kerangka Konseptual

Sumber: Data diolah, 2018

Masing-masing underwriter mempunyai reputasi sesuai dengan hasil kinerja yang ia lakukan dan juga tingkat kepercayaan pasar. Underwriter yang andal serta memiliki reputasi tinggi cenderung lebih dikenal pasar, dan pasar juga memercayai bahwa underwriter yang memiliki citra yang baik dilihat dari reputasinya, tidak akan melakukan tindakan penjaminan terhadap perusahaan yang berkualitas rendah, maka dari itu reputasi underwriter sangat penting (Aini, 2013). Hal ini akan meningkatkan minat calon investor terhadap saham perusahaan. Calon investor yang berminat akan merespon dengan menyatakan minat beli (bid) di harga batas atas saat book building berlangsung (Aryapranata dan Adityawarman, 2017). Menurut Dimovski et al. (2010), fenomena underpricing jarang terjadi pada underwriter yang bereputasi tinggi.

Aryapranata dan Adityawaman (2017), Arman (2012), Kristiantari (2013) Pearlstein (2013), Bakar et al. (2013), Utamaningsih et al. (2013), Wu (2013), dan Dimovski et al. (2011) pada penelitiannya menemukan hasil bahwa reputasi underwriter berpengaruh negatif signifikan terhadap underpricing. Berdasarkan pemaparan hasil teori dan penelitian sebelumnya tersebut, maka muncul hipotesis penelitian, yaitu: 
$\mathrm{H}_{1}$ : Reputasi underwriter berpengaruh negatif signifikan terhadap underpricing.

Ketidakpastian suatu emiten yang berskala besar lebih rendah jika dibanding dengan emiten yang berukuran kecil, karena emiten berskala tinggi maka sentimen atau kondisi pasar biasanya tidak berpengaruh terhadap emiten tersebut (Aini, 2013). Semakin besar aset suatu perusahaan, maka ukuran perusahaannya juga akan semakin besar (Hastuti, 2015). Perusahaan yang memiliki ukuran besar maka akan menyebabkan terjadinya fenomena harga rendah (underpricing) yang lebih kecil karena semakin besar perusahaan dan lebih mapannya suatu perusahaan dapat menghindari risiko yang akan terjadi pada perusahaan tersebut Too et al. (2015)

Penelitian Kristiantari (2012), Pearlstein (2013), Adjasi (2011) dan Pratama (2017) menemukan hasil bahwa ukuran perusahaan berpengaruh negatif signifikan terhadap underpricing saat Initial Public Offering. Berdasarkan hal di atas, maka rumusan hipotesis dalam penelitian ini adalah:

$\mathrm{H}_{2}$ : Ukuran perusahaan berpengaruh negatif signifikan terhadap underpricing.

Investor dapat menggunakan nilai ROE untuk menilai prospek perusahaan dan membuat keputusan investasi. Semakin besar profitabilitas yang diproksikan oleh ROE, menjadikan investor tertarik untuk mencari dan membeli saham perusahaan yang melakukan penawaran perdana tersebut, karena adanya indikasi bahwa di kemudian hari, harapan investor akan mendapatkan tingkat pengembalian modal atas penyertaan modal yang lebih tinggi di perusahaan tersebut. Hal ini mengakibatkan terjadinya kenaikan harga penawaran saham di pasar sekunder yang disebabkan oleh meningkatnya permintaan akan saham tersebut saat diperdagangkan. 
Penelitian Dewi dkk. (2017) dan Witjaksono (2012) menemukan hasil bahwa return on equity berpengaruh negatif signifikan terhadap underpricing yang terjadi saat penawaran saham perdana dari sebuah perusahaan. Berdasarkan hal tersebut, maka dapat dirumuskam hipotesis dalam penelitian adalah:

$\mathrm{H}_{3}$ : Return on equity berpengaruh negatif signifikan terhadap underpricing.

\section{METODE PENELITIAN}

Penelitian ini dilakukan menggunakan pendekatan yaitu kuantitatif asosiatif yang bertujuan untuk menganalisis hubungan antar variabel penelitian. Skema desain penelitian ini dapat digambarkan sebagai berikut:

Pengaruh Reputasi Underwriter, Ukuran Perusahaan, dan Return on Equity terhadap Underpricing saat IPO di Bursa Efek Indonesia

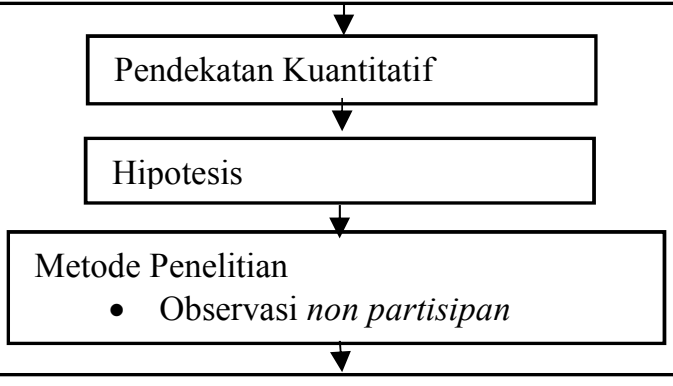

Regresi Linear berganda

Uji Asumsi Klasik

- Uji Normalitas

- Uji Autokorelasi

- Uji Multikolinearitas

- Uji Heterokedastisitas

Uji Statistik t

Uji Kesesuaian Model (Uji F) dan

Koefisien Determinasi $\left(\mathrm{R}^{2}\right)$

Hasil dan Pembahasan

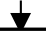

Simpulan dan Saran

Gambar 3. Desain Penelitian

Sumber: Data diolah, 2018 
Penelitian dilakukan di seluruh perusahaan yang melakukan penawaran umum perdana (IPO) di Bursa Efek Indonesia tahun 2013-2017. Obyek pada penelitian ini adalah underpricing yang dialami oleh perusahaan saat IPO. Jenis variabel yang terdapat dalam penelitian ini untuk menganalisis faktor yang dapat menyebabkan terjadinya fenomena underpricing adalah return on equity, ukuran perusahaan, dan reputasi underwriter sebagai variabel bebas dan variabel terikat adalah underpricing.

Tingkat underpricing dapat diukur dengan cara menghitung initial return dari perusahaan-perusahaan yang melakukan Initial Public Offering. Initial return adalah selisih antara harga hari pertama pasar sekunder dengan harga IPO dibagi dengan harga IPO. Menurut (Jogiyanto, 2013:38), rumus initial return adalah sebagai berikut

IR $=\frac{\text { Harga Pertama Pasar Sekunder }- \text { Harga IPO }}{\text { Harga IPO }} \times 100$

Variabel dummy dalam penelitian ini digunakan untuk mengukur variabel reputasi underwriter. Skala yang digunakan untuk variabel reputasi underwriter adalah skala 1 bagi pihak underwriter yang memiliki reputasi yang tinggi dan untuk underwriter yang memiliki reputasi rendah diberi skala 0. Value oleh Bursa Efek Indonesia pada periode 2013-2017 digunakan sebagai dasar perankingan underwriter dalam penelitian ini.

Total aset suatu perusahaan dapat digunakan untuk mengukur ukuran perusahaan yang melakukan IPO pada tahun 2013-2017 yang terdapat pada prospectus, dapat diukur dengan logaritma natural dari total aset suatu perusahaan pada periode terakhir sebelum perusahaan listing sehingga dapat diperoleh variabel 
ukuran perusahaan. Skala data rasio merupakan satuan data yang digunakan untuk mengukur rupiah. Menurut (Jogiyanto, 2000:254), rumus ukuran perusahaan adalah:

Ukuran Perusahaan $=$ Ln $($ Total Aset $)$

Brigham dan Houston (2006:109) mendefinisikan Return on equity (ROE) sebagai rasio laba bersih perusahaan terhadap ekuitas saham biasa yang mengukur pengembalian investasi dari pemegang saham. ROE juga diasumsikan sebagai tingkat harapan investor terhadap pengembalian modal atas modal yang sebelumnya ia tanamkan pada perusahaan yang IPO. Brigham dan Houston (2006: 109), mengungkapkan bahwa ROE dapat dicari dengan rumus:

$\mathrm{ROE}=\frac{\text { Laba bersih }}{\text { Total ekuitas }}$

Penelitian ini dilakukan menggunakan data kuantitatif berupa data harga penawaran saham di pasar perdana, harga closing price pada hari pertama di pasar sekunder perusahaan yang melakukan IPO, total aset dan juga ROE yang terdapat pada dokumen prospektus emiten yang melakukan penawaran saham perdana pada tahun 2013-2017, dan perankingan underwriter. Data dalam penelitian ini menggunakan data sekunder yang didapatkan dari prospektus perusahaan yang dilaporkan sebagai syarat perusahaan dalam melakukan IPO, serta dokumendokumen yang dapat memberikan tambahan informasi data penelitian yang diperoleh di Bursa Efek Indonesia, IDN Financials dan Yahoo Finance. Populasi dalam penelitian ini yaitu seluruh perusahaan yang melakukan IPO pada tahun 2013-2017, sebanyak 122 emiten. Non probability sampling merupakan metode 
penentuan sampel yang digunakan dalam penelitian ini dengan teknik yang digunakan yaitu purposive sampling. Kriteria dalam penentuan sampel penelitian yaitu seluruh perusahaan yang melakukan Initial Public Offering di Bursa Efek Indonesia dan juga mengalami underpricing pada periode 2013-2017. Berdasarkan atas kriteria tersebut, jumlah populasi sebesar 122 emiten dengan 20 diantaranya tidak mengalami underpricing, maka sampel penelitian adalah sebanyak 102 emiten. Metode pengumpulan data pada penelitian ini adalah metode observasi non partisipan. Penelitian menggunakan model regresi linear berganda dengan program SPSS 20. Perhitungan ini digunakan agar dapat menjelaskan dan menganalisis pengaruh antara variabel-variabel bebas, yaitu reputasi underwriter, ukuran perusahaan, dan return on equity terhadap variabel terikatnya yaitu underpricing.

\section{HASIL DAN PEMBAHASAN}

Untuk memperjelas dan mempermudah pemahaman atas hasil penelitian ini, akan dideskripsikan hasil dari masing-masing faktor yang menjadi variabel. Hasil statistik deskriptif dalam penelitian ini disajikan pada tabel 1 berikut.

\section{Tabel 1.}

Hasil Analisis Statistik Deskriptif

\begin{tabular}{lcrrrr}
\hline & $\mathrm{N}$ & Minimum & Maksimum & Mean & Std. Deviation \\
\hline Reputasi Underwriter & 102 & 0 & 1 & 0.06 & 0.236 \\
Ukuran Perusahaan & 102 & 20.21 & 30.12 & 27.3637 & 1.47372 \\
ROE & 102 & -0.78 & 1.21 & 0.1579 & 0.25038 \\
Underpricing & 102 & 0.01 & 1.29 & 0.3319 & 0.27418 \\
Valid $\mathrm{N}$ (listwise) & 102 & & & & \\
Sumber : Data diolah, 2018 & & & & &
\end{tabular}

Berdasarkan hasil olahan data yang terdapat pada Tabel 1. dapat dilihat hasil statistik.deskriptif variabel yang diteliti. Nilai minimum untuk variabel reputasi 
underwriter yaitu 0 , yang dimiliki oleh peringkat underwriter di atas 5 dan nilai maksimum sebesar 1 dimiliki oleh peringkat 1 sampai 5 pada underwriter. Nilai terendah untuk variabel ukuran perusahaan yaitu 20,21 yang dimiliki oleh PT. Jasa Armada Indonesia Tbk. (IPCM) dan nilai tertinggi yaitu 30,12 dimiliki oleh PT. Cikarang Listrindo Tbk. (POWR). Nilai minimum untuk return on equity (ROE) sebesar -0,78 dimiliki oleh PT. Duta Intidaya Tbk. dan nilai maksimum sebesar 1,21 dimiliki oleh PT. Sarana Meditama Metropolitan Tbk. Nilai terendah untuk underpricing sebesar 0,01 dimiliki oleh PT. Intan Baruprana Finance Tbk. (IBFN), PT. Dharma Satya Nusantara Tbk. (DSNG), dan PT. Atmindo Tbk. (AMIN) serta nilai tertinggi sebesar 1,29 dimiliki oleh PT. Ayana Land International Tbk. (NASA).

Analisis regresi linear berganda digunakan untuk mengetahui arah dan besarnya pengaruh variabel bebas terhadap variabel terikat. Hasil perhitungan regresi linear berganda dalam penelitian ini dapat dilihat pada tabel 2 berikut ini.

Tabel 2.

Hasil Analisis Regresi Linear Berganda

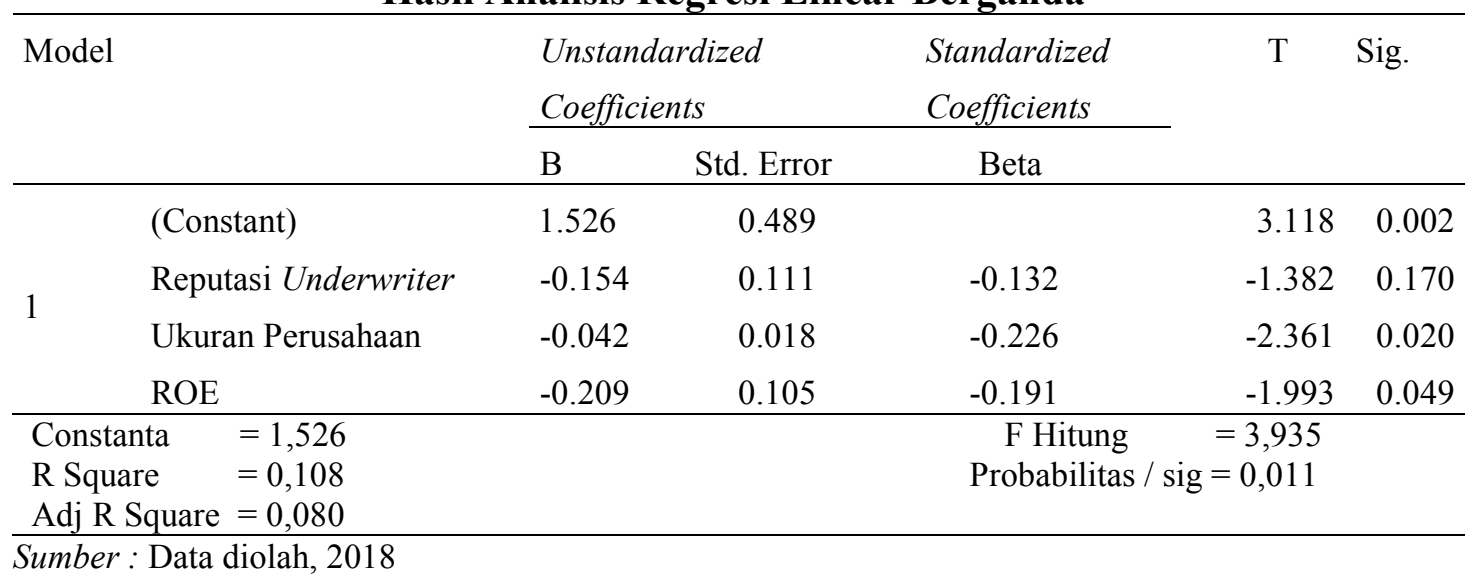


Berdasarkan hasil analisis data yang dilakukan dengan menggunakan program SPSS 20.00 seperti yang disajikan pada Tabel 2. maka persamaan regresi linear bergandanya adalah sebagai berikut.

$$
\mathrm{Y}=1,526-0.154 \mathrm{X} 1-0.042 \mathrm{X} 2-0,209 \mathrm{X} 3
$$

Keterangan:

$\mathrm{Y} \quad=$ Underpricing.

$\mathrm{X} 1=$ Reputasi Underwriter

$\mathrm{X} 2=$ Ukuran Perusahaan.

$\mathrm{X} 3=$ Return on equity

Persamaan regresi linear berganda ini menunjukkan arah dari masing-masing variabel bebas terhadap variabel terikatnya. Tanda negatif dari koefisien regresi variabel bebas berarti mempunyai pengaruh yang berlawanan terhadap underpricing. Persamaan regresi ini dapat diuraikan sebagai berikut : $\alpha \quad=1,526$ artinya jika nilai variabel reputasi underwriter, ukuran perusahaan, dan return on equity sama dengan nol, maka nilai underpricing sebesar 1,526 persen, $\beta 1=$ 0,154 berarti bahwa setiap peningkatan 1 persen reputasi underwriter, maka underpricing akan mengalami penurunan sebesar 0,154 persen dengan asumsi variabel lainnya konstan, $\beta 2=-0.042$ berarti bahwa setiap peningkatan 1 persen ukuran perusahaan, maka underpricing akan mengalami penurunan sebesar 0,042 persen dengan asumsi variabel lainnya konstan, $\beta 3=-0,209$ berarti bahwa setiap peningkatan 1 persen return on equity, maka underpricing akan mengalami penurunan sebesar 0,209 persen dengan asumsi variabel lainnya konstan.

Uji asumsi klasik terhadap model penelitian harus dilakukan sebelum melakukan uji regresi linear berganda. Hal ini dilakukan agar hasil yang diperoleh tidak bias. Uji asumsi klasik ini terdiri atas uji normalitas, uji autokolerasi, uji multikolinearitas, dan uji heteroskedastisitas. 
Uji normalitas memiliki tujuan untuk menguji apakah di dalam suatu model regresi variabel pengganggu atau residual memiliki distribusi normal. Uji statsitik yang digunakan dalam uji normalitas pada penelitian ini adalah uji statistik nonparametrik K-S (Kolomogorov-Smirnov). Pada Tabel 3. di bawah ini diketahui bahwa nilai Asymp. Sig. (2-tailed) sebesar $0,137(0,137>0,05)$. Hal ini menunjukkan bahwa model regresi penelitian ini lolos uji normalitas dan berdistribusi normal.

Tabel 3.

Hasil Uji Normalitas

\begin{tabular}{llr}
\hline N & & $\begin{array}{c}\text { Unstandardized } \\
\text { Residual }\end{array}$ \\
\hline Normal Parameters ${ }^{\mathrm{a}, \mathrm{b}}$ & Mean & 102 \\
& Std. Deviation & $0 \mathrm{E}-7$ \\
& Absolute & .25902178 \\
Most Extreme Differences & Positive & 0.115 \\
Kolmogorov-Smirnov Z & Negative & 0.115 \\
Asymp. Sig. (2-tailed) & & -0.085 \\
a. Test distribution is Normal. & & 1.158 \\
b. Calculated from data. & & 0.137 \\
Sumber : Data diolah, 2018 & & \\
\hline
\end{tabular}

Pengujian autokorelasi dilakukan untuk mengetahui apakah dalam model regresi linear yang digunakan dalam penelitian ini terdapat korelasi antara kesalahan pengganggu atau residual pada periode $t$ dengan kesalahan pengganggu pada periode t-1. Uji autokorelasi dilakukan dengan menggunakan uji Durbin Watson. Pada penelitian ini untuk jumlah data $(n)=102$ dan jumlah variabel bebas $(\mathrm{k})=3$, maka diperoleh nilai $\mathrm{dL}=1,6174$ dan $\mathrm{dU}=1,7383$ sesuai dengan tabel Durbin Watson yang tersedia. Berdasarkan hasil olahan data yang terlihat pada 
Tabel 4. diperoleh nilai Durbin Watson (DW) sebesar 1,753. Nilai DurbinWatson tersebut berada diantara nilai $\mathrm{dU}=1,7383$ dan nilai $4-\mathrm{dU}=2,2617$, atau $1,7383<$ $1,7530<2,2617$ yang merupakan daerah yang tidak terkena autokorelasi, sehingga hasilnya tidak ada korelasi positif maupun negatif., maka layak dipakai untuk memprediksi. Hasil uji autokorelasi dengan menggunakan Durbin-Watson (D-W) test disajikan dalam Tabel 4 sebagai berikut.

Tabel 4.

Hasil Uji Autokorelasi

\begin{tabular}{lccccc}
\hline Model & $\mathrm{R}$ & $R$ Square & $\begin{array}{l}\text { Adjusted } R \\
\text { Square }\end{array}$ & \multicolumn{2}{l}{$\begin{array}{l}\text { Std. Error of the Durbin-Watson } \\
\text { Estimate }\end{array}$} \\
\hline 1 & $0.328^{\mathrm{a}}$ & 0.108 & 0.080 & 0.26296 & 1.753 \\
\hline \multicolumn{2}{l}{ Sumber : Data diolah, 2018} & &
\end{tabular}

Mendeteksi adanya korelasi atau hubungan antar variabel independen dalam model regresi dapat dilakukan melalui uji mulitikoliniearitas. Untuk mengetahui ada tidaknya multikolinearitas di dalam model regresi dapat dilihat dari nilai tolerance dan variance inflation factor (VIF). Hasil Tabel 5. di bawah dapat diamati nilai tolerance untuk seluruh variabel dependen memiliki nilai lebih dari 0,1 dan nilai VIF tidak $>10$ atau kurang dari 10, maka dapat disimpulkan bahwa tidak terjadi multikolinearitas antar variabel bebas tersebut, sehingga dapat disimpulkan bahwa model regresi penelitian ini terbebas dari gejala multikolinearitas. Hasil uji mulitikoliniearitas dalam penelitian ini dapat dilihat dalam Tabel 5 berikut ini.

Pengujian apakah dalam model regresi terjadi ketidaksamaan variance dari residual satu pengamatan ke pengamatan lain, dapat dilakukan uji heteroskedastisitas.Dengan melihat pola gambar scatterplots, dapat dideteksi ada 
atau tidaknya gejala heteroskedastisitas dalam penelitian ini. Hasil uji heteroskedastisitas penelitian ini diperlihatkan pada gambar 2. sebagai berikut.

\section{Tabel 5.}

\section{Hasil Uji Multikolinearitas}

\begin{tabular}{|c|c|c|c|c|c|c|c|}
\hline \multirow[t]{2}{*}{ Model. } & \multicolumn{2}{|c|}{$\begin{array}{l}\text { Unstandardized } \\
\text { Coefficients }\end{array}$} & \multirow{2}{*}{$\begin{array}{c}\text { Standardized } \\
\text { Coefficients } \\
\text { Beta. }\end{array}$} & \multirow[t]{2}{*}{$\mathrm{T}$} & \multirow[t]{2}{*}{ Sig. } & \multicolumn{2}{|l|}{$\begin{array}{l}\text { Collinearity } \\
\text { Statistics. }\end{array}$} \\
\hline & B. & $\begin{array}{l}\text { Std. } \\
\text { Error }\end{array}$ & & & & Tolerance. & VIF. \\
\hline (Constant) & 1.526 & 0.489 & & 3.118 & $\begin{array}{r}0.00 \\
2\end{array}$ & & \\
\hline $\begin{array}{l}\text { Reputasi } \\
\text { Underwriter }\end{array}$ & -0.154 & 0.111 & -0.132 & -1.382 & $\begin{array}{r}0.17 \\
0\end{array}$ & 0.992 & 1.008 \\
\hline $\begin{array}{l}\text { Ukuran } \\
\text { Perusahaan }\end{array}$ & -0.042 & 0.018 & -0.226 & -2.361 & $\begin{array}{r}0.02 \\
0\end{array}$ & 0.991 & 1.010 \\
\hline ROE & -0.209 & 0.105 & -0.191 & -1.993 & $\begin{array}{r}0.04 \\
9\end{array}$ & 0.996 & 1.004 \\
\hline
\end{tabular}

Scalterplot

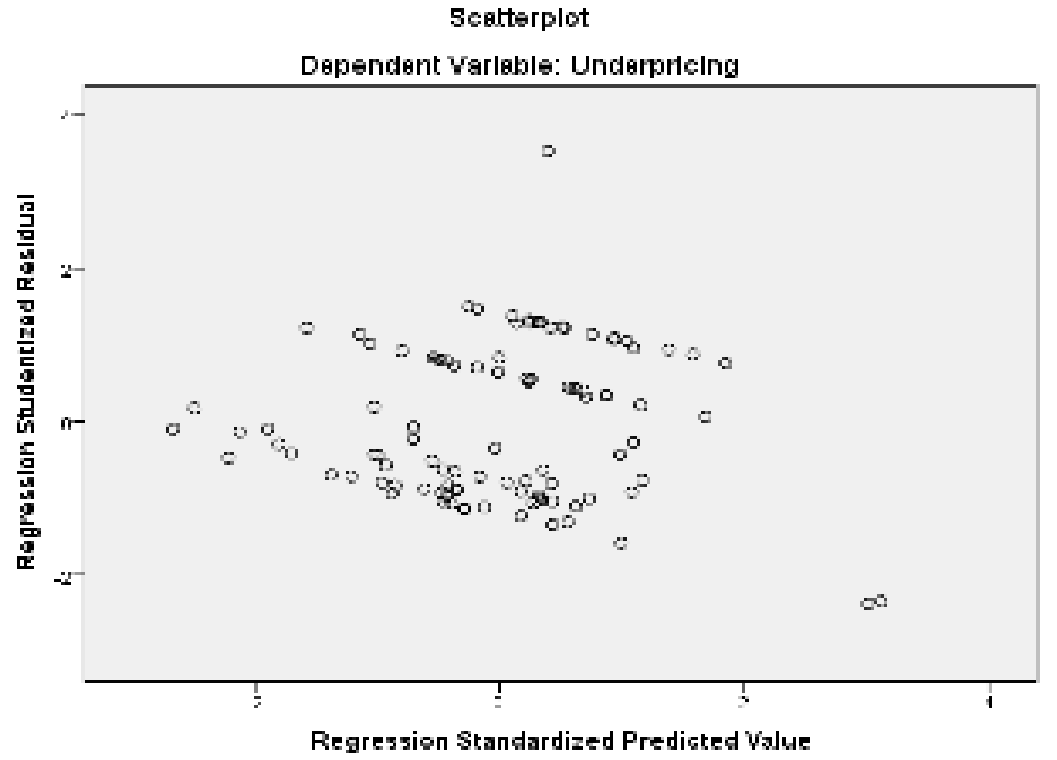

Gambar 2. Hasil Uji Heteroskedastisitas

Sumber : Data diolah, 2018

Ada atau tidaknya gejala heteroskedastisitas dapat dideteksi dengan melihat ada tidaknya pola tertentu pada grafik scatterplot di sekitar nilai X dan Y Gambar hasil uji heteroskedastisitas menggunakan gambar scatterplots di atas, dapat dilihat 
bahwa gambar tersebut tidak menunjukkan suatu pola yang sistematis atau dapat dikatakan acak, sehingga menunjukkan bahwa tidak terdapat heteroskedastisitas pada data.

Berdasarkan hasil yang ditunjukkan dalam Tabel 6. dapat dilhat bahwa variabel dependen (reputasi underwriter, ukuran perusahaan, dan return on equity), secara parsial mempengaruhi variabel independen (underpricing) sebagai berikut.

\section{Tabel 6.}

\section{Analisis Regresi Linear Berganda}

\begin{tabular}{lllll}
\hline Model & Beta & Sig. & Keterangan \\
\hline & Reputasi Underwriter & -0.154 & 0.170 & Tidak berpengaruh \\
& Ukuran Perusahaan & -0.042 & 0.020 & Berpengaruh signifikan \\
& Return on equity & -0.209 & 0.049 & Berpengaruh signifikan \\
\hline
\end{tabular}

$\begin{array}{ll}R \text { Square } & =0.108 \\ \text { Adj } R \text { Square } & =0.080\end{array}$

Sumber : Data diolah, 2018

Nilai koefisien regresi variabel reputasi underwriter adalah sebesar -0,154 dengan signifikansi sebesar 0,170. Berdasarkan hasil signifikansi yang menunjukkan bahwa nilai signifikansi variabel reputasi underwriter sebesar 0,170 lebih besar dari $\alpha=0,05$, maka dapat dikatakan bahwa hipotesis $\left(\mathrm{H}_{1}\right)$ dalam penelitian ini ditolak sehingga dapat disimpulkan bahwa reputasi underwriter tidak berpengaruh terhadap underpricing. Tidak berpengaruhnya vaiabel reputasi underwriter bisa disebabkan oleh kecenderungan investor yang dalam penilaiannya menilai bahwa semua underwriter yang menangani perusahaan dalam pelaksanaan IPO memiliki kompetensi yang sama. Underwriter tidak terlalu dijadikan pertimbangan oleh investor dalam pengambil keputusan untuk membeli saham perusahaan yang melakukan IPO. Calon investor beranggapan pemilihan penjamin 
emisi semata-mata untuk keperluan penanganan IPO, tidak memiliki hubungan dengan perusahaan. Hasil penelitian ini diperkuat oleh penelitian yang dilakukan oleh Kartika (2017) dan Irawan (2016) yang menyatakan bahwa reputasi underwriter tidak berpengaruh terhadap underpricing.

Koefisien regresi variabel ukuran perusahaan adalah sebesar -0.042 dengan taraf signifikansi sebesar 0,020. Berdasarkan hasil signifikansi yang menunjukkan bahwa nilai signifikansi variabel ukuran perusahaan sebesar 0,020 lebih kecil dari $\alpha=0,05$, maka dapat disimpulkan bahwa hipotesis $\left(\mathrm{H}_{2}\right)$ dalam penelitian diterima, hal ini menunjukkan bahwa ukuran perusahaan berpengaruh negatif signifikan terhadap underpricing. Perusahaan yang dikategorikan sebagai perusahaan besar adalah perusahaan yang memiliki total aset yang tinggi, karena total aset mencerminkan kekayaan yang dimiliki oleh perusahaan. Total aset yang tinggi juga dapat menarik kepercayaan investor dan investor mengetahui prospek jangka panjang dari perusahaan sehingga menjadi salah satu keputusan berinvestasi atau menanamkan modalnya, dan hal ini akan memperkecil terjadinya underpricing. Hasil penelitian ini diperkuat oleh penelitian yang dilakukan oleh Kristiantari (2012), Pearlstein (2013), Adjasi (2011), Kartika (2017) dan Pratama (2017) yang menyatakan bahwa ukuran perusahaan berpengaruh negatif signifikan terhadap underpricing.

Nilai koefisien regresi variabel return on equity adalah sebesar -0,209 dengan taraf signifikansi sebesar 0,049. Berdasarkan hasil signifikansi yang menunjukkan bahwa nilai signifikansi variabel return on equity sebesar 0,049 lebih kecil dari taraf $\alpha=0,05$, maka dapat disimpulan bahwa hipotesis $\left(\mathrm{H}_{3}\right)$ diterima. Hal ini 
menunjukkan bahwa return on equity berpengaruh negatif signifikan terhadap underpricing. Semakin besar persentase ROE yang dihasilkan berarti semakin besar laba yang bisa dialokasikan ke pemegang saham. Profitabilitas yang tinggi akan menarik investor untuk menanamkan modalnya ke perusahaan tersebut yang pada akhirnya akan menaikkan harga saham perusahaan dipicu oleh tingginya minat investor terhadap permintaan saham pada perusahaan tersebut. Hasil penelitian ini diperkuat oleh penelitian yang dilakukan oleh Dewi dkk. (2017) dan Witjaksono (2012) yang menyatakan bahwa return on equity berpengaruh negatif signifikan terhadap underpricing.

Penelitian yang dilakukan diharapkan dapat memberikan kontribusi mengenai pengaruh reputasi underwriter, ukuran perusahaan dan return on equity terhadap underpricing saat IPO. Penelitian ini menambah bukti empiris bahwa variabel reputasi underwriter tidak memiliki pengaruh yang signifikan terhadap tingkat underpricing, sedangkan ukuran perusahan dan return on equity memiliki pengaruh negatif signifikan terhadap tingkat underpricing. Ukuran perusahan dan return on equity merupakan cerminan reaksi pasar terhadap signal yang diberikan perusahaan kepada investor. Temuan ini mendukung teori signal yang mengatakan bahwa seharusnya suatu perusahaan memberikan signal bagi para investor, sehingga asimetri informasi dapat diminimalisasi. Bagi perusahaan yang akan melakukan IPO di masa yang akan datang, disarankan agar memperhatikan pencatatan pada laporan keuangannya dengan baik. Dalam penelitian ini, variabel ukuran perusahaan dan return on equity yang terdapat pada laporan keuangan diperhitungkan oleh investor. Bagi investor yang berminat untuk membeli saham 
melalui pasar modal, maka hasil penelitian ini dapat dijadikan referensi dalam melakukan pembelian. Terutama pada ukuran perusahaan dan return on equity yang terdapat pada laporan keuangan perusahaan karena kedua variabel ini memiliki pengaruh yang signifikan terhadap tingkat underpricing.

\section{SIMPULAN DAN SARAN}

Penelitian ini dilakukan terhadap perusahaan yang melakukan IPO di BEI dari tahun 2013 sampai dengan 2017. Metode yang digunakan dalam penelitian ini merupakan observasi non partisipan, dengan kriteria penentuan sampel menggunakan purposive sampling, sehingga diperoleh sampel perusahaan sebanyak 102 perusahaan. Penelitian ini menggunakan analisis regresi berganda dan uji asumsi klasik.

Berdasarkan hasil analisis yang telah diuraikan dilakukan, maka dapat diambil kesimpulan: (1) Reputasi underwriter tidak berpengaruh terhadap underpricing. Hal ini memperlihatkan bahwa tinggi ataupun rendahnya reputasi dari underwriter tidak menentukan tingkat underpricing perusahaan yang melakukan IPO pada tahun 2013-2017. (2) Ukuran perusahaan berpengaruh negatif signifikan terhadap underpricing. Hal ini berarti semakin tinggi ukuran perusahaan, maka semakin rendah tingkat underpricing pada perusahaan yang melakukan IPO pada tahun 2013-2017. (3) Return on equity berpengaruh negatif signifikan terhadap underpricing. Hal ini menunjukkan bahwa meningkatnya return on equity mengakibatkan underpricing semakin rendah pada perusahaan yang melakukan IPO pada tahun 2013-2017. 
Penelitian ini memilki keterbatasan, yaitu hanya mencari dan menganalisis bagaimana pengaruh variabel reputasi underwriter, ukuran perusahaan, dan return on equity terhadap fenomena underpricing yang terjadi di Bursa Efek Indonesia, sedangkan sebenarnya masih banyak variabel lain yang dapat digunakan untuk megetahui seberapa besar variabel tersebut mempengaruhi underpricing. Berdasarkan uraian pada bab-bab sebelumnya, maka saran- saran yang dapat diajukan terkait dengan penelitian adalah dalam pengambilan keputusan investasi pada emiten yang melakukan tahap Initial Public Offering, selain mempertimbangkan return on equity dan besar kecilnya perusahaan yang diproksikan oleh variabel ukuran perusahaan karena terbukti mempunyai pengaruh signifikan terhadap underpricing sesuai dengan, investor juga dapat memperhitungkan variabel-variabel dominan lainnya, seperti return on asset (ROA) yang terdapat dalam laporan keuangan untuk mengetahui prospek perusahaan yang tidak bisa peneliti teliti karena keterbatasan penelitian. Bagi peneliti berikutnya agar menambah variabel lain yang berhubungan dengan rasiorasio keuangan perusahaan lainnya seperti likuiditas dan solvabilitas, agar hasil dari penelitian ini dapat lebih baik lagi dalam membuktikan hipotesis yang ditetapkan, serta diharapkan agar periode pengamatan diperpanjang dan sampel yang digunakan lebih besar, serta agar hasil penelitian yang didapat nantinya dapat digeneralisasikan.

\section{REFERENSI}

Adjasi, C.K.D., Osei, K.A., \& Fiawoyife, E.U. (2011). Explaining underpricing of IPOs in frontier markets: Evidence from the Nigeria Stock Exchange. Research in International Business and Finance, 25, 255-265. 
Aini, S. N. (2013). Faktor-faktor yang Mempengaruhi Underpricing Saham pada Perusahaan IPO Di BEI Periode 2007-2011. Jurnal Ilmiah Manajemen, 1(1), 88-102.

Apriliani, K. M. (2015). Analisis Faktor-Faktor yang Mempengaruhi Underpricing Ketika Initial Public Offering (IPO) di Bursa Efek Indonesia (BEI) Tahun 2008-2012. Jurusan Akuntansi Fakultas Ekonomi Dan Bisnis Universitas Muhammadiyah Surakarta, 6(1), 1-15.

Arman, A. (2012). Pengaruh Umur dan Ukuran Perusahaan, Reputasi Underwriter, dan Return on equity Terhadap Tingkat Underpricing Saham di Bursa Efek Indonesia, 107-120.

Aryapranata, E. K. \& Adityawarman. (2017). Pengaruh Reputasi Auditor, Reputasi Underwriter, dan Persentase Free Float terhadap Tingkat Underpricing pada Initial Public Offering (Studi Empiris pada Perusahaan yang Go public di Bursa Efek Indonesia Periode Tahun 2012-2014). Diponegoro Journal of Accounting, 6(2) 1-9.

Asiri, B. K, \& Haji, A. J. (2015). The Determinants of IPO Underpricing in the GCC Countries. International Journal of Arts \&amp; Sciences, 8(4), 205-218.

Bakar, N. B. A., \& Uzaki, K. (2014). The Impact of Underwriter Reputation and Risk Factors on the Degree of Initial Public Offering Underpricing: Evidence from Shariah-Compliant Companies. IAFOR Journal of Business \& Management, 1(1), 1-16.

Brigham, F. E. \& Houston, J. F. (2006). Dasar-dasar Manajemen Keuangan Buku 1. Edisi Kesepuluh. Jakarta: Salemba Empat.

Boudriga, A., Slama, B., Sarra \& Boulila, N. (2010): What determines IPO Underpricing? Evidence from a Frontier Market, 1-33.

Darmadji, T. \& Fakhruddin, H. M. (2012). Pasar Modal di Indonesia Pendekatan Tanya Jawab. Edisi Ketiga. Jakarta: Salemba Empat.

Dewi, K. M. S., Tripalupi, L. E., Haris, I. A. (2017). Pengaruh Return on equity (ROE) dan Earning per Share (EPS) terhadap Underpricing pada Saham Perdana Di Bursa Efek Indonesia Tahun 2016. E-Journal Ekonomi Jurusan Pendidikan Ekonomi Undiksha, 10(2), 1-10.

Dimovski, W., Philavanh, S., Brooks, R. (2011). Underwriter reputation and underpricing: evidence from the Australian IPO market, 37, 409-426.

Fahmi, Irham. (2012). Manajemen Investasi Teori dan Soal Jawab. Jakarta: Salemba Empat.

Hastuti, R. T. (2015). Analisis Faktor-faktor yang Mempengaruhi Fenomena Underpricing Saham Pada Saat IPO di Bursa Efek Indonesia Pada Periode 2008-2013. Jurnal Ekonomi, 20(1), 1-19.

Hermuningsih, S. (2012). Pengantar Pasar Modal Indonesia. Edisi Pertama. Yogyakarta: UPP STIM YKPN. 
Indriani, S., \& Marlia, S. (2014). The Evidence of IPO Underpricing in Indonesia 2009-2013. Review of Integrative Business and Economics Research, 4, 229316.

Irawan, F.N. (2016). Analisis Faktor - Faktor Yang Mempengaruhi Underpricing Saat Initial Public Offering Pada Perusahaan Yang Terdaftar Di Bursa Efek Indonesia Tahun 2010-2014 . Universitas Muhamadiyah Surakarta.

Islam, M. A., Ali, R., \& Ahmad, Z. (2012). Does Dual Listing Affect Underpricing of Initial Public Offerings? Evidence from Bangladesh Capital Market. Economics, Management, and Financial Markets, 7(1), 81-101.

Islam, M. A., Ali, R., \& Ahmad, Z. (2010). An Empirical Investigation of the Underpricing of Initial Public Offerings in the Chittagong Stock Exchange, 2(4), 36-46.

Hartono, J. (2013). Teori Portofolio dan Analisis Investasi, Edisi 7. Yogyakarta: BPFE.

Hartono, J. (2014). Teori Portofolio dan Analisis Investasi, Edisi 9. Yogyakarta: BPFE.

Jones, T. L. \& Mushfiq, U. S. (2010). Endogenous examination of underwriter reputation and IPO returns, Managerial Finance, 36(4), 284-293.

Kartika, G. A. S. K. \& Putra, I. M. P. D. (2017). Faktor-Faktor Underpricing Initial Public Offering Di Bursa Efek Indonesia , I', E-Jurnal Akuntansi Universitas Udayana, 19, 2205-2233.

Kristiantari, I. D. A. (2013). Analisis Faktor-faktor yang Mempengaruhi Underpricing Saham pada Penawaran Saham Perdana Di Bursa Efek Indonesia. Jurnal Ilmiah Akuntansi dan Humanika, 2(2), 3-109.

Mahatidana M. R. A. \& Yunita, I. (2017). An Examination Factors Influencing Underpricing of IPOs in Financial and Manufacturing Industries on The Indonesia Stock Exchange over The Period of 2011-2016. International Journal of Scientific and Research Publications, 7(11), 457-464.

Maolaa, M. (2017). Analisis Faktor Yang Mempengaruhi Underpricing Pada Saat Penawaran Perdana ( Initial Public Offering ) di Bursa Efek Indonesia, 8(2), 190-203.

Pearlstein, J. (2013). Measures of Issuer and Underwriter Power: Resource Based Tools for Analyzing IPO Underpricing, 7(1), 93-109.

Pratama, E. (2017). Pengaruh Reputasi Underwriter, Ukuran Perusahaan, dan Jenis Industri Terhadap Underpricing Saat Ipo Di Bursa Efek Indonesia (Studi Pada Perusahaan di BEI). E-Jurnal Manajemen Unud, 6(1), 492-520.

Puspita, T. (2011). Analisis Faktor - Faktor Yang Mempengaruhi Tingkat Underpricing Saham Pada Saat Initial Public Offering (Ipo) Di Bursa Efek Indonesia Periode 2005 - 2009. Universitas Diponegoro. 
Risqi I. A. \& Harto. (2013). Analisis Faktor-Faktor yang Mempengaruhi Underpricing Ketika Initial Public Offering (IPO) di Bursa Efek Indonesia. Diponegoro Journal of Accounting, 2(3), 1-7.

Rosyidah, L. (2014). Pengaruh Karakteristik Perusahaan, Reputasi Underwriter dan Reputasi Auditor Terhadap Tingkat Underpricing. Jurnal Ilmu Manajemen, 2(3), 965-978

Samsul, M. (2006). Pasar Modal \& Manajemen Portofolio. Jakarta: Erlangga.

Sari, A. M., \& Isynuwardhana, D. (2015). Analisis Faktor- Faktor yang Mempengaruhi Tingkat Underpricing pada Saat Initial Public Offering ( Ipo ) di Bursa Efek Indonesia Periode 2010-2014, 2(2), 1589-1595.

Schenone, C. (2010). The Effect of Banking Relationships on the Firm's IPO Underpricing, 19(6), 2904-2958.

Sugiyono, (2013). Metode Penelitian Bisnis (Pendekatan Kuantitatif, Kualitatif, dan R\&amp;D). Bandung: Alfabeta.

Sunariyah. (2011). Pengantar Pengetahuan Pasar Modal. Edisi Keenam. Yogyakarta: UPP STIM YKPN.

Tandelilin, E. (2010). Analisis Investasi dan Manajemen Portofolio. Yogyakarta. BPFE Yogyakarta

Undang-Undang Pasar Modal Republik Indonesia Nomor 8 Tahun 1995.

Utamaningsih, A., Tandelilin E., Husnan S., \& Sartono, R. A. (2013). Asymmetric Information in the IPO Underwriting Process on the Indonesia Stock Exchange: Pricing, Initial Allocation, Underpricing, And Price Stabilization. Journal of Indonesian Economy and Business, 28(3), 311-321.

Van Heerden, G. \& Alagidede, P. (2012). Short run underpricing of initial public offerings (IPOS) in the Johannesburg Stock Exchange (JSE)', Review of Development Finance. University of Cairo., 2(3-4), 130-138.

Widayani, N. L. U. M. (2013). Tingkat Underpricing Dan Reputasi Underwriter, 4(1), 159-176.

Witjaksono, L. S. (2012). Analisis Faktor-Faktor Keuangan yang Mempengaruhi Fenomena Underpricing pada Perusahaan Sektor Keuangan yang Terdaftar Di Bursa Efek Indonesia 2002-2010. Berkala Ilmiah Mahasiswa Akuntansi, 1(1), 33-37.

Wu, Z., \& Wan, D. (2014). Does Underwriter Reputation Promote Fair Pricing Behavior in the IPO Process?-Evidence from ChiNext-Listed Firms. The Journal of Applied Business Research, 30(2), 615-624.

Zhou, J., \& Lao, L.-J. (2012). Analysis of Influencing Factors of IPO Underpricing in ChiNext. Physics Procedia, 33, 846-851. 